Policy and Practice Brief

\title{
An overview of the Paycheck Protection Program (PPP) loans and implications for agricultural enterprise recovery from COVID
}

\author{
Iryna Demko a \\ Cleveland State University \\ Ana Claudia Sant'Anna b \\ West Virginia University \\ Kathleen (Chyi Lyi) Liang c * \\ Center for Environmental Farming Systems and \\ North Carolina Agricultural and Technical State University
}

Submitted August 8, 2021 / Published online October 28, 2021

Citation: Demko, I., Sant'Anna, A. C., \& Liang, K. (C. L.). (2021). An overview of the Paycheck

Protection Program (PPP) loans and implications for agricultural enterprise recovery from

COVID. Journal of Agriculture, Food Systems, and Community Development, 11(1), 201-208.

https://doi.org/10.5304/jafscd.2021.111.003

Copyright (C) 2021 by the Authors. Published by the Lyson Center for Civic Agriculture and Food Systems. Open access under CC-BY license.

Abstract

In this policy and practice brief, we analyze the U.S. Paycheck Protection Program (PPP). The PPP

${ }^{a}$ Iryna Demko, Research Associate, Center for Economic Development, Maxine Goodman Levin College of Urban Affairs, Cleveland State University, Cleveland, OH, USA; i.demko@,csuohio.edu

b Ana Claudia Sant'Anna, Assistant Professor, Division of Resource Economics and Management, West Virginia University, Morgantown, WV, USA;

anaclaudia.santanna@mail.wvu.edu

c* Corresponding author: Kathleen (Chyi Lyi) Liang, W. K. Kellogg Distinguished Professor of Sustainable Agriculture, Director, Center for Environmental Farming Systems, College of Agriculture and Environmental Sciences, North Carolina Agricultural and Technical State University; Coltrane Hall 105 B, 1601 East Market Street; Greensboro, NC 27411 USA; +1-336-285-4683; cliang@ncat.edu

${ }^{1}$ All currencies are U.S. dollars. provided loans to support businesses during the COVID-19 pandemic. Some businesses received timely relief from the PPP loans, while some were not able to acquire assistance. Production agriculture received 617,128 PPP loans totaling $\$ 17$ billion. ${ }^{1}$ The reach of PPP loans across the country was broad. In $80 \%$ of U.S. zip codes, at least one farm received a PPP loan. The average size of the

\section{Funding Disclosure}

This study was funded in part using Levin College Women's Fund Award; EDA CARES Act Supplemental Award ID\# ED20CHI3070034; Scientific Article No. 3416 of the West Virginia Agricultural and Forestry Experiment Station, Morgantown. This material is based on work that is partially supported by the National Institute of Food and Agriculture, U.S. Department of Agriculture, Multi-State Hatch Project under WVA00731. The statements, findings, conclusions, and recommendations are those of the author(s) and do not necessarily reflect the views of the U.S. Economic Development Administration or the U.S. Department of Commerce. 
loan in agriculture $(\$ 27,744)$ was substantially smaller than the national average $(\$ 74,156)$. The authors conducted interviews with PPP recipients and present some findings from those. The most recent data reveal challenges and opportunities for agricultural businesses, depending on their scale of operations and regional disparities. Community organizations working with small agriculturerelated businesses need to be aware of various impacts while providing future assistance.

\section{Keywords}

Paycheck Protection Program (PPP), Agriculture, Entrepreneurship, COVID-19, Pandemic, Governmental Support

\section{Background of the Issues}

Entrepreneurs and small businesses are the heart and soul of our communities. According to the Small Business Administration (U.S. SBA)'s Office of Advocacy, more than 30 million small businesses in the U.S. represent $99.9 \%$ of all U.S. businesses (U.S. SBA, 2020a). Nearly half of all Americans are employed by small businesses, which the SBA generally defines as firms with fewer than 500 employees. In considering the industrial sectors, agriculture has one of the highest shares of small business employment $(86 \%)$ by industry, followed by construction $(82 \%)$ and real estate $(68 \%)$.

Unfortunately, the COVID-19 pandemic has created unprecedented impacts on all companies and employees worldwide. The U.S. economy mirrors these global concerns. The U.S. government provided support to small businesses by implementing the Paycheck Protection Program (PPP). This policy and practice brief analyzes the PPP created as part of the Coronavirus Aid, Relief, and Economic Security (CARES) Act. We provide a descriptive and geographical analysis of the PPP loan program by analyzing secondary data provided by SBA for the years of 2020 and 2021. Summary statistics are presented at various levels of importance: zip code level, business size, experience, loan amount, and years of the program (i.e., 2020 and 2021). This allows a greater understanding of program participants and loan distribution to agriculture.
By the time the CARES Act was passed on March 27, 2020, small business owners were already severely affected by disruptions related to COVID-19: 60\% had already laid off at least one worker (Humphries et al., 2020). The number of active small business owners in the U.S. plummeted by 3.3 million, or $22 \%$, from February to April 2020 (Fairlie, 2020). More than 97,900 businesses had permanently closed during the pandemic as of the second quarter of 2020 (Yelp, 2020). Almost $80 \%$ of respondents to the Small Business Credit Survey, conducted by the U.S. Federal Reserve Banks in September and October 2020 , reported a decline in revenues and a $50 \%$ reduction in their workforce between 2019 and 2020 (Federal Reserve Banks, 2021).

Many scholars struggle to comprehend the magnitude and complexity of entrepreneurship development in a "new normal" with multiple shocks (Acs et al., 2017; Alvedalen \& Boschma, 2017; Mayer \& Motoyama, 2020). Several studies have explored the impact of COVID-19 on small businesses in the U.S. For example, Bartik et al. (2020) surveyed over 5,800 small businesses early in the pandemic (between March 28 and April 4, 2020) and reported that mass layoffs and closures triggered higher risks of business closure as the pandemic extended to a longer period of threats. Small businesses became financially fragile and were hesitant to seek aid due to bureaucratic hassles and difficulties navigating the application process. Humphries, Neilson, and Ulyssea (2020) found that the smallest businesses were the least aware of the government assistance programs available and had the slowest growth in awareness after the passage of the CARES Act, never catching up with larger businesses. Demko and Sant'Anna (2021) also found that smaller businesses had less knowledge about the programs available when compared to larger businesses.

\section{What Do We Know About the PPP Loan in Agricultural Sectors?}

In response to a small business crisis, Congress established the PPP, administered by SBA, to help small businesses, self-employed workers, sole proprietors, eligible nonprofits, and tribal businesses keep their employees on the payroll. Agricultural 
enterprises were eligible to receive loans on the same basis as other small businesses (Hungerford et al., 2021). While the PPP has been one of the largest economic stimulus programs in U.S. history, the SBA also offered other, smaller disaster relief programs to assist small businesses during the COVID-19 pandemic, such as the Economic Injury Disaster Loan (EIDL), EIDL Advance, Targeted EIDL Advance, Supplemental EIDL Advance, Restaurant Revitalization Fund, Shuttered Venue Operators Grant, and SBA Debt Relief program.

According to experts, "The scale of PPP is historic" (Parilla \& Liu, 2020, para. 2). From April 3, 2020, through May 29, 2021, during the first and second PPP draws, production agriculture received
617,128 loans totaling $\$ 17$ billion. Production agriculture includes industries under North American Industry Classification System (NAICS) Code 11Agriculture, Forestry, Fishing and Hunting. Using national firm-level data on all PPP loans released by SBA, we mapped the program coverage in agriculture. The reach of PPP loans across the country was broad. In $80 \%$ of U.S. zip codes, at least one farm received a PPP loan in 2020 or 2021 (Figure 1). At the same time, the average size of the PPP loan in production agriculture $(\$ 27,744)$ was smaller than the average across all 24 industrial sectors of the economy, where the average was $\$ 74,156$.

PPP reached smaller farms in 2021 as the average PPP loan was three times smaller, $\$ 19,204$

\section{Figure 1. Distribution of Paycheck Protection Program (PPP) Loans in Agriculture}

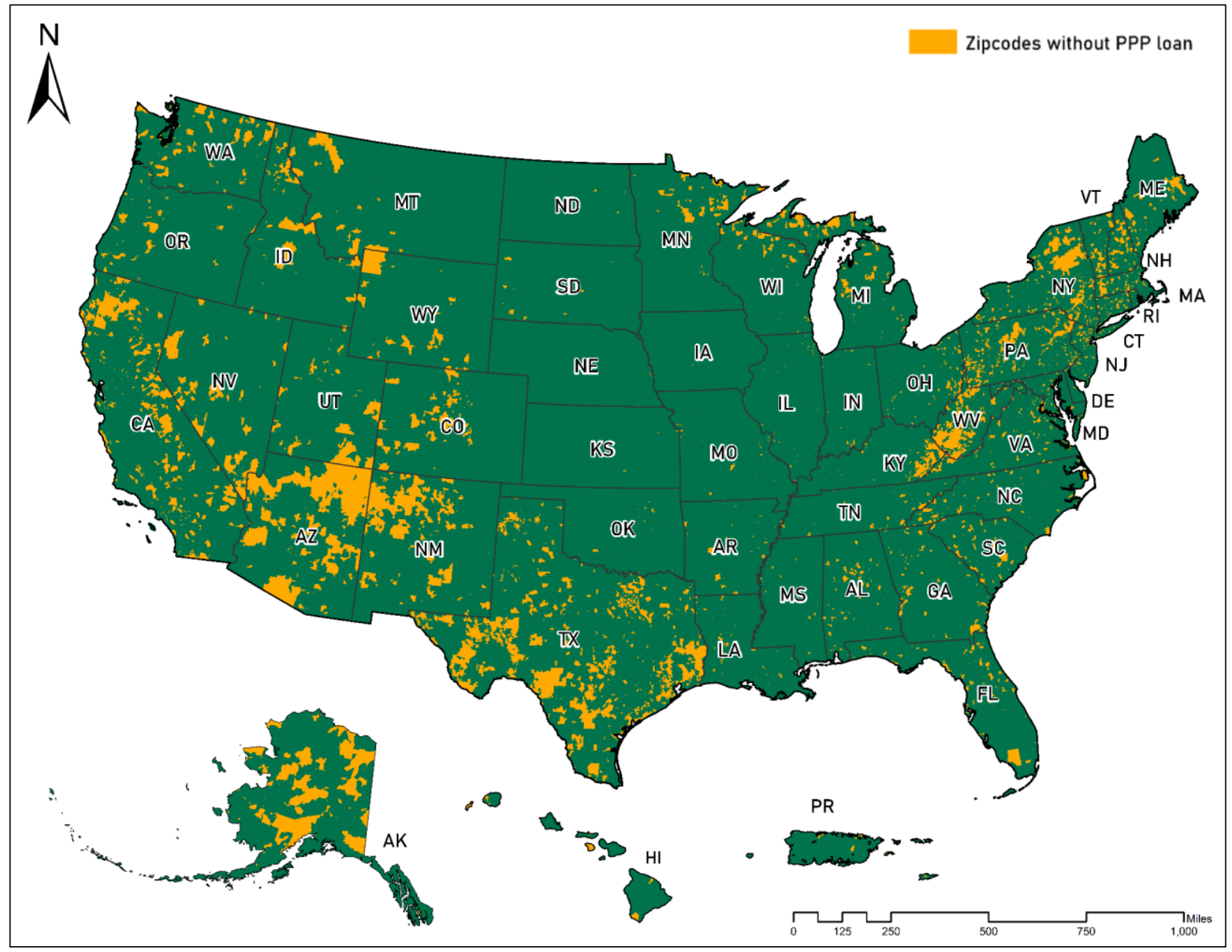

Source: Analysis of 2020 and 2021 PPP data released by the Small Business Administration (SBA) in June 2021. 
compared to $\$ 58,136$. In 2020 , during the first draw of PPP loans (approvals from April 3 through August 8), production agriculture received $\$ 8$ billion in PPP. Later, the program was reopened from January 11 until May 31, 2021. In 2021, the amount of PPP issued to agriculture increased by $\$ 1.4$ bil lion $(+18 \%)$ in comparison to 2020 . In addition, the number of PPP loans to production agriculture entities saw a three-fold increase, from 135,374 in 2020 to 481,754 in 2021 (Table 1).

Farms with fewer than five employees received $50 \%$ of the approved amount ( $\$ 8.3$ billion) and $90 \%$ of all loans $(554,190)$. The average size of PPP loans to these borrowers was $\$ 15,038$ (Figure 2 and Appendix, Table A1). Beginning farmers (those with fewer than two years of experience) received 8,238 PPP loans totaling $\$ 578$ million. The average loan size received by a beginning farmer was $\$ 70,155$, on par with the average loan size received by any small business in the U.S. (Appendix, Table A2).

\section{Discussion and Recommendations for Research, Policy, and Practice}

Many U.S. government agencies have spent significant time and resources to support enterprise and

\section{Table 1. Paycheck Protection Program (PPP) Loans to Agriculture}

\begin{tabular}{|c|c|c|c|c|c|}
\hline & Timeline & Loan Amount & $\begin{array}{c}\text { Number of } \\
\text { Loans }\end{array}$ & $\begin{array}{l}\text { Median } \\
\text { Loan Size }\end{array}$ & $\begin{array}{c}\text { Average Loan } \\
\text { Size }\end{array}$ \\
\hline First PPP draw & April 3-August 8, 2020 & $\$ 7,870,051,274$ & 135,374 & $\$ 20,000$ & $\$ 58,136$ \\
\hline Second PPP draw & January 11-May 31, 2021 & $\$ 9,251,580,911$ & 481,754 & $\$ 20,741$ & $\$ 19,204$ \\
\hline Total for PPP & 37 weeks and 6 days & $\$ 17,121,632,186$ & 617,128 & $\$ 20,537$ & $\$ 27,744$ \\
\hline
\end{tabular}

Source: Analysis of 2020 and 2021 PPP data released by SBA on June 1, 2021. All values in US\$.

Figure 2. Paycheck Protection Program (PPP) Loan Recipients in Agriculture by Business Size

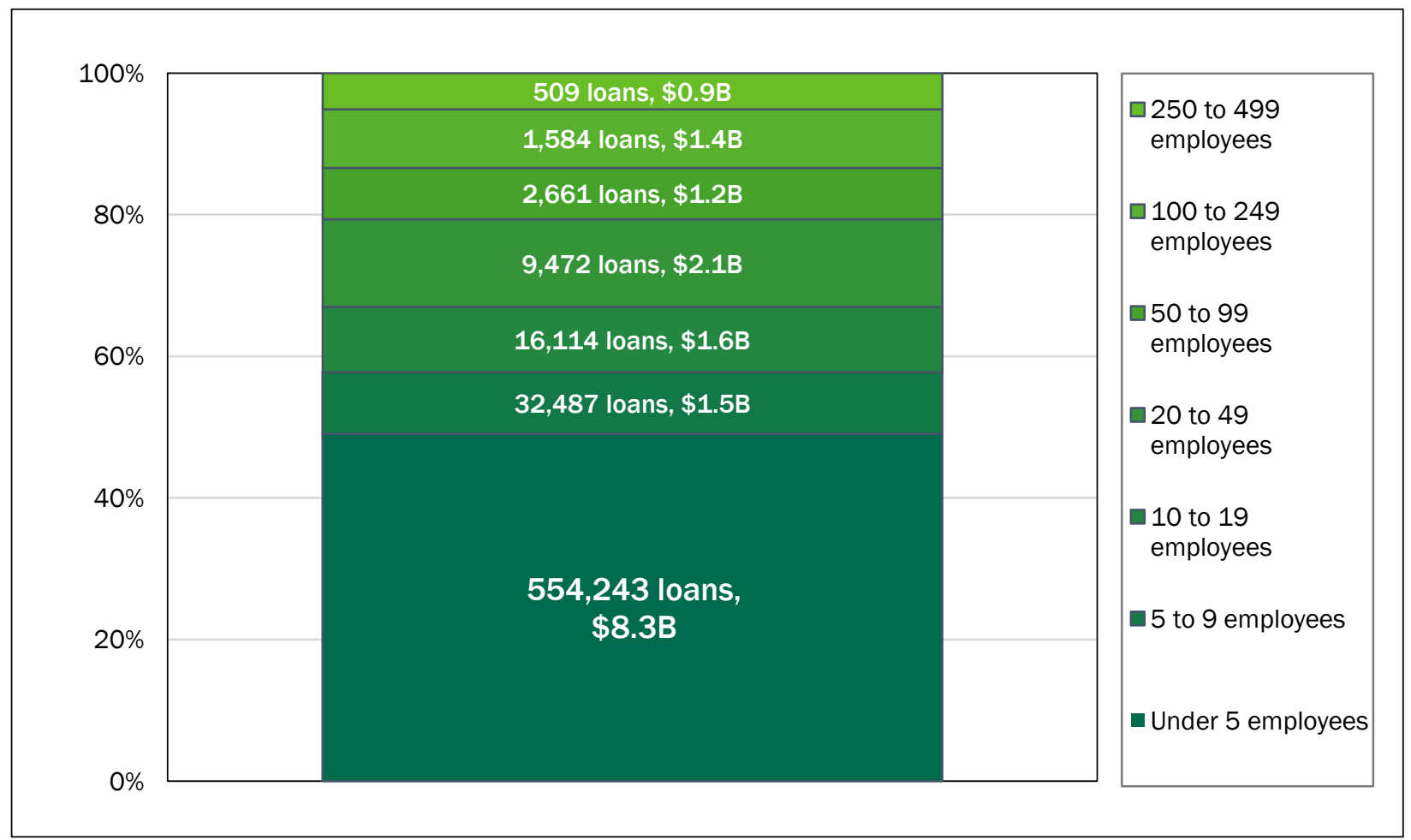

Source: Analysis of 2020 and 2021 PPP data released by SBA on June 1, 2021. 
community development attempting to improve social and economic mobility. Challenges compromise these programs' outcomes and effectiveness (Aziz, 1984). Scholars have shared concerns that rural communities are generally underperforming compared to metropolitan areas, and the gap is widening in wealth distribution and community well-being (Drabenstott, 2003; Falcone et al., 1996; Henderson \& Novack, 2002; Lyons, 2002; Porter et al., 2004). In 2021, SBA made changes to focus the COVID-19 relief program on businesses in low- and moderate-income (LMI) communities (Schweitzer \& Borawski, 2021). As a result, the rate of loans to small businesses in rural areas increased by $12 \%$ compared to the daily average rate of loans before the changes (SBA, 2021). However, the exclusive application period only lasted two weeks, while the first PPP draw in 2020 lasted 18 weeks, and the second draw in 2021 lasted for over 19 weeks.

The authors performed interviews with a variety of small businesses to provide a qualitative assessment of business' experiences applying for and receiving PPP loan funds in 2020. Small businesses interviewed voiced that the exclusive PPP application period created by SBA was a valuable change, though its duration was too short. Policymakers should look into dedicating a longer period of time for the PPP loan application to smaller businesses. This action is essential if the PPP loan program aims to reach more diverse businesses in terms of ownership and size.

Some articles reported mixed impacts of PPP loans on U.S. agriculture. According to the American Farm Bureau Federation (2020), PPP loans had minimal impact on farmers and ranchers due to their limited use of the program. Reasons included (1) farmers and ranchers had limited or no experiences applying for SBA loan programs, (2) farming enterprises differ in characteristics and nature of operations in comparison to other small businesses (for example, having different tax forms and a labor force that varies according to production and seasons), and have more complicated asset structure dynamics (for example, land and equipment) on one farm. Additionally, the slow release of guidance on the PPP posed limitations for farmers and ranchers to complete and prepare paper- work because farming activities are usually determined a year before. Therefore, policymakers should design future programs by taking into account the particular characteristics of the business it aims to target.

While conducting interviews, Demko and Sant'Anna (2021) confirmed that the lack of clarity and transparency about the PPP application was an issue. Although SBA provided an application form, every lender had its own form, format, or portal. Lenders also required different information on their respective applications. For more than 30 years, SBA has been prohibited by law from providing disaster assistance to agricultural businesses (SBA, 2020b). However, in May 2020, changes in legislation allowed American farmers, ranchers, and other agricultural businesses to have access to the Economic Injury Disaster Loan (EIDL) program. In such circumstances, agricultural enterprises were less likely to have established relationships with SBA. They would have benefited from technical assistance and guidance through the SBA's PPP application and forgiveness processes. One business owner shared, "I would ask for help from the banker, and they said to talk to my accountant. My accountant said you have to talk to your banker." This highlights the importance of communication strategies and technical assistance to guarantee the success of a public policy. Future research could investigate which communication strategies are more cost effective for which type of public policy depending on the target group.

Many interview respondents did not realize that rent, mortgage, and utility payments could be included in the requested PPP amount. As a result, they missed out on the opportunity to receive higher forgivable loan amounts from SBA. Most businesses do not have experience in doing their financials. For these, there was a steep learning curve to understand out how to apply for PPP. "For us, it was all foreign language," said one PPP recipient. In the case of agriculture, $55 \%$ of approved loans covered payroll only. Research is also needed to understand how asymmetric information affected access to PPP due to business characteristics. This would help identify best practices for similar future programs. 
PPP helped many industries to stay afloat, and some would not have survived without it. In some cases, PPP recipients in the first round were not eligible in the second round because they did not suffer a $25 \%$ loss of revenue in 2020 . Here, the first PPP draw helped these businesses maintain their workforce and continue operating normally, avoiding large negative effects on their revenue. The U.S. was the only country in the world to implement a payroll subsidy via banks and financial institutions (Hamilton, 2020). While PPP offered necessary financial relief by allowing small businesses to continue paying their employees, this type of support inevitably is insufficient to keep some businesses afloat. One business owner said, "eight weeks of pay cannot be enough to sustain a business for six months of the downturn." Many community organizations have been assisting those small businesses who have survived the economic loss and mental stress of the pandemic to figure out how to recover more fully from the COVID disaster. To many agricultural businesses, recovery is a long road filled with unknowns. PPP offered some relief to a limited number of businesses in the agriculture and food industry. More transformative strategies and well-defined and well explained policies will need to be established soon to prevent permanent damage to entrepreneurs and small businesses who are the heart and the soul of our communities.

\section{References}

Acs, Z. J., Stam, E., Audretsch, D. B., \& O’Connor, A. (2017). The lineages of the entrepreneurial ecosystem approach. Small Business Economics, 49(1), 1-10. https://doi.org/10.1007/s11187-017-9864-8

Alvedalen, J., \& Boschma, R. (2017). A critical review of entrepreneurial ecosystems research: Towards a future research agenda. European Planning Studies, 25(6), 887-903. https://doi.org/10.1080/09654313.2017.1299694

American Farm Bureau Federation. (2020). PPP out of funds, but impact on agriculture was minimal. https://www.fb.org/market-intel/ppp-out-of-funds-but-impact-on-agriculture-was-minimal

Aziz, S. (1984). Rural development_Some essential prerequisites. International Labor Review, 123(3), $277-285$.

Bartik, A. W., Bertrand, M., Cullen, Z., Glaeser, E. L., Luca, M., \& Stanton, C. (2020). The impact of COVID-19 on small business outcomes and expectations. Proceedings of the National Academy of Sciences, 117(30), 17656-17666. https://doi.org/10.1073/pnas.2006991117

Demko, I., \& Sant'Anna, A. C. (2021). Impact of race and gender on the SBA Paycheck Protection Program (PPP) loan amounts. Social Science Research Network (SSRN). https://doi.org/10.2139/ssrn.3864218

Drabenstott, M. (2003). A new era for rural policy. Federal Reserve Bank of Kansas City Economic Review, 88(4), 81-98. https://www.kansascityfed.org/documents/970/2003-A \%20New $\% 20 \mathrm{Era} \% 20$ for $\% 20$ Rural $\% 20$ Policy.pdf

Fairlie, R. (2020). The impact of COVID-19 on small business owners: Evidence from the first three months after widespread social-distancing restrictions. Journal of Economics \& Management Strategy, 29(4), 727-740. https://doi.org/10.1111/jems.12400

Falcone, T., Allen, L. D., \& Vatter-Vance, R. (1996). A comparison of rural and urban economic development programs in Pennsylvania. Economic Development Review, 14(2), 63.

Federal Reserve Banks. (2021). Small business credit survey: 2021 report on employer firms. https://www.fedsmallbusiness.org/medialibrary/FedSmallBusiness/files/2021/2021-sbcs-employer-firms-report

Hamilton, S. (2020, September). From survival to revival: How to help small businesses through the COVID-19 crisis (Policy Proposal 2020-14). The Hamilton Project. https://www.brookings.edu/wpcontent/uploads/2020/09/PP Hamilton Final.pdf

Henderson, J., \& Novack, N. (2002). Will rains and a national recovery bring rural prosperity? Federal Reserve Bank of Kansas City Economic Review, 88(1), 77-96. https://www.kansascityfed.org/documents/1662/2003Will\%20Rains $\% 20$ and $\% 20 \mathrm{a} \% 20$ National $\% 20$ Recovery $\% 20$ Bring $\% 20$ Rural $\% 20$ Prosperity $\% 3 \mathrm{~F}$.pdf

Humphries, J. E., Neilson, C., \& Ulyssea, G. (2020). The evolving impacts of COVID-19 on small businesses since the CARES Act (Cowles Foundation Discussion Paper No. 2230). Social Science Research Network (SSRN). https://doi.org/10.2139/ssrn.3584745 
Hungerford, A., Effland, A., \& Johansson, R. (2021). Agricultural and food policy response to COVID-19. Choices, 36(3). https://www.choicesmagazine.org/choices-magazine/theme-articles/agricultural-market-response-to-covid19/agricultural-and-food-policy-response-to-covid-19

Lyons, T. S. (2002). Building social capital for rural enterprise development: Three case studies in the United States. Journal of Developmental Entrepreneurship, 7(2), 193-216.

Mayer, H., \& Motoyama, Y. (2020). Entrepreneurship in small and medium-sized towns. Entrepreneurship \& Regional Development, 32(7-8), 467-472. https://doi.org/10.1080/08985626.2020.1798556

Parilla, J., \& S. Liu. (2020). Across metro areas, COVID-19 relief loans are helping some places more than others [Blog post]. Brookings. https://www.brookings.edu/blog/the-avenue/2020/07/14/across-metro-areas-covid-19-relief-loansare-helping-some-places-more-than-others/

Porter, M. E., Ketels, C. H. M., Miller, K., \& Bryden, R. T. (2004). Competitiveness in rural U.S. regions: Learning and research agenda. Institute for Strategy and Competitiveness, Harvard Business School. https://clustermapping.us/sites/default/files/files/resource/Competitiveness in U.S. Rural Regions.pdf

Schweitzer, M. E., \& Borawski, G. (2021, May 28). How well did PPP loans reach low- and moderate-income communities? (Economic Commentary No. 2021-13). Federal Reserve Bank of Cleveland. https://doi.org/10.26509/frbc-ec-202113

U.S. Small Business Administration [SBA]. (2020a). 2020 small business profile. U.S. SBA Office of Advocacy. https://cdn.advocacy.sba.gov/wp-content/uploads/2020/06/04144224/2020-Small-Business-Economic-Profile$\underline{\text { US.pdf }}$

U.S. SBA. (2020b, May 4). SBA to make Economic Injury Disaster Loans available to U.S. agricultural businesses impacted by COVID-19 pandemic [Press release]. https://www.sba.gov/article/2020/may/04/sba-make-economic-injurydisaster-loans-available-us-agricultural-businesses-impacted-covid-19

U.S. SBA. (2021, March 9). Fact sheet: Changes to Paycheck Protection Program by Biden-Harris Administration increase equitable access to relief [Press release]. https://www.sba.gov/article/2021/mar/09/fact-sheet-changes-paycheck-protectionprogram-biden-harris-administration-increase-equitable-access

Yelp. (2020, July). Increased consumer interest in May correlates with COVID-19 hot spots in June, according to the Yelp Economic Average (Q2, 2020). https://www.yelpeconomicaverage.com/yea-q2-2020 
Appendix

Table A1. Paycheck Protection Program (PPP) Loan Recipients in Agriculture by Business Size

\begin{tabular}{lrrrr}
\hline Business Size & Loan Amount & Number of Loans & Median Loan Size & Average Loan Size \\
\hline No (0) employees & $\$ 507,867$ & 53 & $\$ 6,160$ & $\$ 9,582$ \\
\hline 1 to 4 employees & $\$ 8,334,109,387$ & 554,190 & $\$ 17,985$ & $\$ 15,038$ \\
\hline 5 to 9 employees & $\$ 1,474,244,595$ & 32,487 & $\$ 38,400$ & $\$ 45,380$ \\
\hline 10 to 19 employees & $\$ 1,562,332,173$ & 16,114 & $\$ 86,800$ & $\$ 96,955$ \\
\hline 20 to 49 employees & $\$ 2,107,368,419$ & 9,472 & $\$ 199,500$ & $\$ 222,484$ \\
\hline 50 to 99 employees & $\$ 1,231,982,198$ & 2,661 & $\$ 434,513$ & $\$ 462,977$ \\
\hline 100 to 249 employees & $\$ 1,407,453,605$ & 1,584 & $\$ 790,650$ & $\$ 888,544$ \\
\hline 250 to 499 employees & $\$ 865,667,043$ & 509 & $\$ 1,283,600$ & $\$ 1,700,721$
\end{tabular}

Source: 2020 and 2021 PPP data released by SBA on June 1, 2021.

Table A2. Paycheck Protection Program (PPP) Loan Recipients with Fewer than Two Years of Business Experience

\begin{tabular}{lcccc}
\hline & Loan Amount & Number of Loans & Median Loan Size & Average Loan Size \\
\hline Agriculture & $\$ 577,940,325$ & 8,238 & $\$ 20,400$ & $\$ 70,155$ \\
\hline All industries & $\$ 42,943,743,902$ & 608,347 & $\$ 20,566$ & $\$ 70,591$ \\
\hline
\end{tabular}

Source: 2020 and 2021 PPP data released by SBA on June 1, 2021. 